\title{
DIAGNOSIS DINI DAN TATALAKSANA HIPOTIROID
}

\author{
M. Bastanta Tarigan ${ }^{\bowtie}$, Jekson Martiar Siahaan \\ Faculty Kedokteran, Universitas Methodist Indonesia, Medan, Indonesia \\ Email: tariganbastanta62@.gmail.com
}

DOI: https://doi.org/10.46880/methoda.Vol11No2.pp145-148

\begin{abstract}
Hypothyroidism is a state of thyroid hormone deficiency ranging from mild to moderate symptoms. Hypothyroidism can be caused by congenital abnormalities, ablation, radiation, surgery and most often autoimmune. Hypothyroidism is more common in women than in men. Thyroid hormone is very important for fetal growth and currently the TSH test is a screening for early detection of hypothyroidism. Thyroid hormone deficiency will cause fetal defects and even fetal death. In adults, thyroid hormone deficiency causes hyperlipidemia and increased cardiovascular risk. Several guidelines provide recommendations for thyroid hormone administration based on clinical symptoms, pregnancy, age, risk and TSH levels.
\end{abstract}

Keyword: Hypothyroid, Levothyroxine, TSH.

\begin{abstract}
ABSTRAK
Hypothyroid adalah suatu keadaan kekurangan hormon tiroid mulai dari gejala ringan sedang sampai berat. Hypothyroid dapat disebabkan kelainan kongenital, ablasi, radiasi, operasi dan paling sering autoimun. Hypothyroid paling sering pada perempuan dibandingkan laki-laki. Hormon tiroid sangat penting untuk pertumbuhan janin dan saat ini pemeriksaan TSH merupakan skrening deteksi dini hypothyroid. Kekurangan hormon tiroid akan menyebabkan cacat janin bahkan kematian janin. Pada orang dewasa kekurangan hormon tiroid menyebabkan hiperlipidemia dan meningkatnya resiko kardiovaskular. Beberapa guidelines memberi rekomendasi pemberian hormon tiroid berdasarkan gejala klinis, kehamilan, faktor usia, resiko dan kadar TSH. Agar penyerapan levotiroksin maksimal sebaiknya diberikan pada waktu perut kosong dan dihindari pemberian bersamaan obat yang menganggu penyerapan levotiroksin.
\end{abstract}

Kata Kunci: Hypothyroid, Levotiroksin, TSH.

\section{PENDAHULUAN}

Hipotiroid adalah suatu keadaan penurunan fungsi tiroid mulai dari ringan dengan gejala yang samar (subclinical hypothyroid) dengan dan komplikasi, overt hypothyroid dan lebih berat yaitu miksedema. Laboratorium subclincal hipotiroid dengan kadar tiroksin atau tetrayodotironin (T4) dan triyodotirosin (T3) normal dan peningkatan tiroid stimulating hormon (TSH), overt hipotiroid dengan kadar T4 dan T3 yang rendah dan tiroid stimulating hormon (TSH) tinggi dan miksedema dengan nilai $\mathrm{T} 3$ dan $\mathrm{T} 4$ yang sangat menurun dan TSH yang sangat tinggi.

\begin{abstract}
Hipotiroid menyebabkan komplikasi hipertensi, dislipidemia, gangguan kardiovaskular, infertilitas, gangguan fungsi kognitif hingga gangguan neuromuskular. Miksedema adalah hipotiroid berat yang bila tidak dilakukan penanganan segera akan menimbulkan kematian.
\end{abstract}

\section{TINJAUAN PUSTAKA}

\section{Prevalensi}

Hipotiroid lebih dominan pada wanita dibandingkan pria dan prevalensi meningkat sesuai peningkatan usia. Hampir 2\% wanita usia antara 70-80 tahun mengalami overt hipotiroid 
dan wanita usia lebih 50 tahun prevalensi hipotiroid lebih tinggi lagi yaitu berkisar 5\%$10 \%$. Prevalensi hipotiroid saat ini berkisar 4-5\% dan subklinikal hipotiroid 4-15\%. Insiden overt hipotiroid selama kehamilan 0,3-0,5\% sedangkan subklinikal hipotiroid dengan kehamilan 2-3\%.

Miksedema adalah hipotiroid berat hanya terjadi $0,1 \%$ dari semua kasus hipotiroid.

\section{Etiologi}

Etilogi dari hipotiroid adalah primer yaitu autoimum tiroiditis (Hashimoto), kongenital atau defek kelenjar tiroid, tiroidektomi, radiasi atau ablasi dan kerusakan jaringan tiroid akibat amyloidosis dan sarkoidosis. Gangguan sintesis hormon tiroid akibat kekurangan jodium defek enzim kongenital dan obatan seperti tionamid, amiadaron, litium dan karbimazole. Sekunder produksi TSH tertekan akibat adenoma apopleksi dan infiltrasi sarkoidosis di pituitari dan tersier akibat defesiensi thyrotropin releasing hormone (TRH) di hipotalamus. Hipotiroid juga dapat disebabkan aksi hormon tiroid di perifer mengalami resitensi.

\section{Faktor Yang Berperan dalam Hipotiroid}

Faktor-faktor yang berperan dalam hipotiroid adalah:

1. Riwayat kelainan autoimum pada penyakit lain seperti diabetes tipe 1, rematoid arthritis, multiple sclerosis, celiac disease, penyakit addison, anemia perniosa dan vitiligo.

2. Radio active iodine dan radiasi

3. Tiroidektomi

4. Sindrom Turner dan Down

\section{IMPLEMENTASI PENELITIAN}

\section{Gambaran Klinis}

Pada hipotiroid yang mengalami overt sering tampak gejala seperti kulit kering dan kasar bertambah berat badan, tidak tahan udara dingin, jarang berkeringat, konstipasi, suara serak, kram, lelah, ingatan berkurang dan gangguan pendengaran sedangkan pada pemeriksaan fisik dijumpai pergerakan lambat, periorbita odema, kulit dingin, pergelangan kaki menyentak.
Pada subklinis hipotiroid sering dengan gejala yang tidak jelas dan diperlukan kecermatan dalam anamnese pemeriksaan fisik dan laboratorium. Beberapa kasus yang terlambat dalam diagnose dan pengobatan telah dijumpai komplikasi ringan seperti dislipidemia, hipertensi dan komplikasi berat yaitu gangguan kardiovaskular dan miksedema.

\section{Diagnosa.}

Pemeriksaan dapat dilakukan penghitungan skor berdasarkan skala Billewicz dan Zulewski namun mempunyai sensitivity dan spesipity yang rendah oleh karena selain pemeriksaan klinis dan fisik juga diperlukan pemeriksaan laboratorium. Tiroiditis Hashimoto adalah penyakit autoimum yang menyebabkan produksi antibodi yang abnormal yang merusak enzim tiroid peroksidase yang dikenal sebagai anti tirod peroksidase antibodi (TPO Ab). Pemeriksaan TPO Ab dilakukan pada kecurigaaan tiroiditis autoimun, wanita yang mengalami keguguran berulang dan infertilitas. Bila di curigai hipotiroid dengan keluhan sakit kepala, gangguan penglihatan perlu dilakukan pemeriksaan fungsi hormon dan imaging pituitari.

\section{Skrening untuk pemeriksaan hipotiroid}

Oleh karena gejala dan tanda hipotiroid sering tanpa gejala maka perlu dilakukan skrening yaitu pada wanita dan pria diatas usia 35 tahun setiap 5 tahun, usia diatas atau sama 60 tahun, wanita diatas 50 tahun dengan disertai gejala hipotitoid, infertil atau sering mengalami keguguran.

\section{Hipotiroid dengan komplikasi}

Hanya sedikit studi menjelaskan bagaimana efek terhadap kasus hipotiroid yang tidak mendapat pengobatan. Studi kohort Danish Observational memperlihatkan peningkatan resiko kematian dan resiko kardiovaskular meningkat pada usia diatas atau sama dengan 60 tahun dan resiko sedikit berkurang pada usia 65 tahun dengan TSH $<10 \mathrm{mU} / \mathrm{L}$.

Penelitian kohort retrospektif oleh Taiwan National Health Insurance Research memperlihatkan resiko kardiovaskular pada 
tiroiditis Hashimoto dan resiko berkurang bila mendapat levotiroksin.

Penelitian yang dilakukan The Women's Health Initiative Study dan Studi Cardiovascular Health Study tidak menemukan insiden kardiovaskular pada hipotiroid ringan dan juga hipotiroid dengan atau tanpa anti TPO antibodi.

The Atherosclerosis Risk in Communitas Study pasien yang mild dan progresif TSH memperlihatkan hiperlipidemia tetapi tidak menemukan efek kardiovaskular.

Penelitian yang dilakukan Third National Health and Nutrition Examination Survey (NHANES) pada mild hipotiroid memperlihatkan resiko kematian dibandingkan dengan yang eutiroid.

Penelitian yang dilakukan oleh Chlalit Health Medical Organization memperlihatkan kematian pada pasien yang sudah usia lanjut dan berkorelasi dengan peningkatan TSH. Dari semua penelitian sama-sama memperlihatkan ada dugaan peningkatan resiko kardiovaskular dan peningkatan kematian pada pasien $<65$ tahun dan $\mathrm{TSH}>10 \mathrm{mU} / \mathrm{L}$ dan sebagian penelitian memperlihatkan resiko kardiovaskular.

Penelitian yang dilakukan oleh Stott dkk pada Thyroid hormone Replacement for Untreated Older Adults with Subclinical Hypothyroid (TRUST) Study. Dengan pemberian levotiroksin pada pasien usia lanjut dengan mild hipotiroid tidak ada perbedaaan bermakna pada kelompok yang mendapat levotiroksin dengan placebo dalam Thyroid Symptom Score dan Tiredness Score. Secara keseluruhan studi ini memperlihatkan bahwa tidak ada perbaikan gejala pada serum TSH yang sedikit tinggi, namun ada perbaikan pada TSH antara 10-12 $\mathrm{mU} / \mathrm{L}$. Studi ini juga memperlihatkan ada peningkatan resiko kardiovaskular dan kematian pada pasien $<65$ tahun. Surrogate marker seperti hipertensi, hiperkolesterolemia, profile aterogenik lipoprotein mengalami perbaikan setelah mendapan levotiroksin (Stott et al., 2017).

\section{Rekomendasi pengobatan Hipotiroid.}

ATA (American Thyroid Association 2012 dan 2014) TSH kurang atau sama $10 \mathrm{mU} / \mathrm{L}$ dengan faktor yang bersifat individual. TSH lebih besar atau sama dengan $10 \mathrm{mU} / \mathrm{L}$ dengan peningkatan cardiovascular (Cappola et al., 2019; Garber et al., 2012).

ETA (European Thyroid Association 2013) usia $<$ 65-60 tahun dengan TSH $<10 \mathrm{mU} / \mathrm{L}$ dengan pertimbangan ada gejala dan TSH lebih besar atau sama dengan $10 \mathrm{mU} / \mathrm{L}$ dan Usia $>70$ tahun dengan TSH $<10 \mathrm{mU} / \mathrm{L}$ dilakukan evaluasi tanpa pengobatan dan TSH lebih besar $10 \mathrm{mU} / \mathrm{L}$ atas dasar gejala.

\section{Pengobatan Overt hipotiroid}

Pasien usia $<60$ tahun tanpa penyakit kardiovaskular diberikan levotiroksin 1,6 $\mathrm{mcg} / \mathrm{kg}$ perhari dan evaluasi TSH 6-8 minggu dan dilakukan penyesuaian dosis atas dasar gejala dan evaluasi TSH.

Pasien $>60$ tahun dengan kardiovaskular diberikan low dose levotiroksin 12,5-50 mcg perhari dan titrasi 12,5-25 meg setiap 4-8 minggu dengan monitoring TSH setiap 6-8 minggu. Penyesuaian dosis levotiroksin atas dasar gejala dan pemeriksaan TSH.

\section{Edukasi pemberian levotiroksin}

Guna mendapat penyerapan yang optimal sebaiknya diberikan 1 jam sebelum sarapan pagi atau 4 jam setelah makan atau 2-3 jam setelah makan malam. Sebaiknya dihindari bersamaan dengan obat lain seperti zar besi, kalsium, proton pump inhibisi, antasida, olistrat dan obat lainnya. Karena pemberian jangka panjang maka harus dilakukan edukasi sebelum mendapat levotiroksin melalui dosis, cara makan dan efek samping obat. Overtreatmen levotiroksin harus dihindari dimana tujuan pemberian adalah untuk menekan TSH tanpa menimbulkan gejala kelebihan hormon tiroid. Kelebihan obat akan menimbulkan palpitasi, gangguan kardiovaskular dan osteoporosis.

\section{Pengobatan mild hipotiroid}

Usia $<70$ tahun dan atau tanpa gejala dengan $\mathrm{TSH}>10 \mathrm{mU} / \mathrm{L}$. 
Pemeriksaan TSH 6-8 minggu. Penyesuaian dosis atas dasar gejala dan nilai TSH.

Usia lebih besar atau sama dengan 70 tahun dengan $\mathrm{TSH}<10 \mathrm{mU} / \mathrm{L}$ dengan atau tanpa gejala, adanya goiter, TSH yang meningkat dan anti TPO antibodi dan dengan atau tanpa gejala kardiovaskular.

Bila gejala sudah hilang dalam 3-6 bulan atau ada efek samping levotiroksin maka obat di hentikan.

Pengobatan dapat dilakukan bila ada gejala dan nilai $\mathrm{TSH}>10 \mathrm{mU} / \mathrm{L}$.

\section{Pengobatan Koma Miksedema}

Koma miksedema adalah suatu keadaan hipotiroid berat yang mortalitas $10-45 \%$ dan biasanya terjadi pada lanjut usia dengan faktor infeksi adalah infeksi, trauma, operasi, serangan jantung, stroke, gagal napas, perdarahan. Gejala adalah hipotermia, bradikardi, hipoventilasi dengan komplikasi efusi pleura dan ileus. Gejala sistem saraf pusat adalah kejang, stupor dan koma. Serum tiroksin, T3 sangat rendah dan TSH yang sangat tinggi. Skor Glasgow 8-10 menandakan suatu koma miksedema. Pengobatan levotriroksin, triodotironin (T3), glukokortikoid, cairan dan atasi komplikasi dan faktor pencetus.

\section{KESIMPULAN}

Perlu dilakukan skreening untuk mendiagnosis hipotiroid. Hipotiroid yang tidah diobati dapat menimbulkan komplikasi dislipidemia, obesitas dan kardiovaskular.

Replacement terapi dengan levotiroksin dilakukan atas dasar usia, resiko kardiovakular dan pemeriksaan TSH.

\section{DAFTAR PUSTAKA}

Alrehaili, M. A., Alharbi, A. A., Siraj, M. M., Halawani, M. S., Nughays, R. O., Altemani, A. F., ... Wasfi, L. A. (2018). Causes, diagnosis, and management of hypothyroidism. The Egyptian Journal of Hospital Medicine, 71(1), 2250-2252.

Cappola, A. R., Desai, A. S., Medici, M., Cooper, L. S., Egan, D., Sopko, G., ... Kudenchuk, P. J. (2019). Thyroid and cardiovascular disease: research agenda for enhancing knowledge, prevention, and treatment. Circulation, 139(25), 2892 2909.

Chaker, L., Bianco, A. C., Jonklaas, J., \& Peeters, R. P. (2018). Hypothyroidism and hypertension: fact or myth?-Authors' reply. The Lancet, 391(10115), 15501562.

Chiovato, L., Magri, F., \& Carlé, A. (2019). Hypothyroidism in Context: Where We've Been and Where We're Going. Advances in Therapy, 36(S2), 47-58. https://doi.org/10.1007/s12325-01901080-8

Garber, J. R., Cobin, R. H., Gharib, H., Hennessey, J. V., Klein, I., Mechanick, J. I., ... Woeber, K. A. (2012). Clinical practice guidelines for hypothyroidism in adults: cosponsored by the American Association of Clinical Endocrinologists and the American Thyroid Association. Thyroid, 22(12), 1200-1235.

Peeters, R. P. (2017). Subclinical hypothyroidism. New England Journal of Medicine, 376(26), 2556-2565.

Popoveniuc, G., Chandra, T., Sud, A., Sharma, M., Blackman, M. R., Burman, K. D., ... Wartofsky, L. (2014). A Diagnostic Scoring System for Myxedema Coma. Endocrine Practice, 20(8), 808-817. https://doi.org/10.4158/EP13460.OR Stott, D. J., Gussekloo, J., Kearney, P. M., Rodondi, N., Westendorp, R. G., Mooijaart, S., ... Du Puy, R. (2017). Study protocol; Thyroid hormone Replacement for Untreated older adults with Subclinical hypothyroidism-a randomised placebo controlled Trial (TRUST). BMC Endocrine Disorders, $17(1), 1-17$. 